\title{
MAIN FEATURES OF THE OFFSETS IN DEFENSE TRADE
}

\author{
Venelin Terziev ${ }^{1}$ and Nikolay Nichev ${ }^{2}$ \\ ${ }^{1}$ Professor, Ph.D., D.Sc. (National Security), D.Sc. (Ec.), University of Rousse, Rousse, Bulgaria; \\ National Military University, Veliko Tarnovo, Bulgaria; University of Telecommunications and Post, \\ Sofia, Bulgaria, terziev@skmat.com \\ ${ }^{2}$ Colonel Associate Professor, Ph.D., National Military University, Veliko Tarnovo, Bulgaria, \\ nicheff@gmail.com
}

\begin{abstract}
The collaboration in the sphere of production and deliveries of defense products undergo changes under the influence of the development of the international economic relations, thus exercising influence not only on the acquisition of defense products, but also on the functioning of the participating economic operators. By means of a better collaboration and coordination of the planning in the sphere of defense the states will be able to develop their military abilities using a more effective way, regarding the expenses, and without negative consequences for their sovereignty. The paper presents the main features and the opportunities of the offset transactions, their advantages and disadvantages in the global market for defense products. The study outlines the place of the offset transactions for the acquisition of weapon and equipment.
\end{abstract}

Keywords: offset transactions, market of defense products

\section{INTRODUCTION}

The form and the methods for collaboration in the sphere of production and deliveries of defense products undergo changes under the influence of the development of the international economic relations, thus exercising influence not only on the acquisition of defense products, but also on the functioning of the participating economic operators. The collaboration in the sphere of production and deliveries of defense products is developing in conformity with the regularities for the development of the world economy and of international trade, with the increasing competition between the manufacturers and the tradesmen of defense products, with the requirements of international legislation and with the established international traditions.

The researchers include to the regularities of functioning of the defense products market also (2002), (2017a):

- The military and the military-technical interest in the production for military use are proportional to the military and military-technical potential of the countries. 
- The political opportunities of the countries, exporting weapon, to promote their military production and to lobby when big transactions are being implemented in this sphere, are connected with their political influences and their political rating in the global community.

- The export opportunities of the exporting countries of defense production depend on their economic resources, i.e. the export volume is directly proportional to the economic potential of the state.

The political, commercial and economic principles can be related to the principles of functioning of the defense products market.

The following belong to the political principles:

- transparency of the relations - promotion of the legal trade of weapons;

- confidentiality of the relations and keeping of commercial and others secrecies - obliges unconditionally to respect the ethics in the commercial relations;

- observing of the international obligations, international sanctions and export regimes - restrictions are being imposed upon the legal arms trafficking;

- Prevention of the re-export of arms without the consent of the state-supplier - to avert the illegal diversion and distribution in general of arms around the world.

To the commercial principles belong:

- Assurance of mutual benefit when concluding commercial transactions, looking for mutually acceptable compromises, including of the criterion "effectiveness - expenses";

- Implementation of monitoring of the market and of the marketing activities, comparison of the own abilities to the abilities of other suppliers of weapon and laying down a set of measures, which could promote the defense products to the potential buyers;

- Maintaining of a level of average world prices for the delivered defense products and prevention of material damages resulting from maintaining of fixed prices;

- Providing of credits for purchasing of defense products and outline of commercial perspectives for the next few years.

To the economic principles belong:

- Assistance of the countries-importers for establishing of a national defense industry, including by means of joint ventures, by selling of licenses for the manufacturing of military production, thus ensuring loading of the national capacity and transforming the expenditures for purchasing of defense products into expenses on own production;

- Encourage the development of the national economies of the state-importers by means of fulfillment of obligations according to contracts for delivery of weapon and military equipment using offset programs.

The present research depicts different points of view and performs an analysis of the main features of the offset transactions and the opportunities for their application for the acquisition of weapon and equipment for the needs of the Bulgarian Army under the conditions of the globalization and the international collaboration.

\section{MAIN FEATURES OF THE OFFSET TRANSACTIONS}

Despite the segmentation of the world market of defense products, the competition between the exporters of military products proceeds continuously. At the same time, the competition for niches in the world arms market acquires new shapes, using the full arsenal of economic and non-economic methods. In this connection it ought to be emphasized, that the offset agreements are part of the usual commercial relations and are increasingly considered to be a new and quite effective marketing mechanism for conquering of new positions on the market or for preserving the traditional markets.

The analysis of the accessible literature and the studies of a number of researchers define the offset as a specific sort of economic activity possessing the following peculiarities (2017a), (2016b):

1) The activity, performed within the frames of the offset, is being financed by the export of defense products. The total volumes of the undertaken offset obligations amount to dozens of billions of dollars. The United States implement approximately $20 \%-25 \%$ of the total sum of the annual volumes of the world arms export. The desideration of the exporters is to minimize the expenditures during the fulfillment of the offset obligations and to reduce the volume of the offset liabilities, also to minimize the expenses during their implementation. The economic condition of the state-importer depends on the performance of the 
undertaken offset obligations. An important task of the importers is to increase the volume of the offset programs in such spheres of the national industry, which are not attractive to foreign investors, and to gain access to the newest technologies.

2) The refusal of the exporter to perform an offset in any country, which applies the offset practice, results in the loss of the transaction for the delivery of defense products and in the exclusion of the opportunity for further military-technical collaboration.

3) The development of offset programs and the fulfillment of the offset obligations, in particular when it's connected with the transference to the importing countries of high tech abilities and technologies with a possible double usage, requires the engagement of a specially trained personnel, possessing skills in the sphere of investment projects, in the theory and practice of the offset. Usually the elaboration of a particular offset program, depending on the specific character of the national requirements, on the volume, kind and contents of the implemented offset, necessitates the establishing of a temporal work group, which must possess the relevant knowledge.

4) At the moment, most of the countries-exporters of defense products, acting at their traditional markets, tend to use preliminary offset agreements. During these offset pre-agreements, long before the announcement of the tender requirements of an expected large transaction, connected with the acquisition of defense products, the exporting countries enter offset transactions and start the preliminary fulfillment of their obligations.

Such policy gives an advantage to the companies during their participation in the main tender for the supply of weapon and military equipment.

5) The offset practice gives a definite advantage to the companies from states-exporters in the possible winning of a market segment of unusual or inaccessible until that moment national and regional markets.

Georgi lanakiev emphasizes that at the strongly competitive market of defense products during the age after the Cold War, the offset agreements are among the most powerful instruments for winning of Export contracts. Such cases were noted, when during the process of evaluation of the competitive quotations a bigger significance was paid to the quality of the offset offers, than to the technical features of the defense products, which are being negotiated (2006). That's why, out of the point of view of the contractor, each inability to meet the demands of the importer can result in giving back offset agreements to the rivals. This marketing instrument is especially important to the defense industry of the United States for the reason, that there is no official financing for the companies-exporters of defense products and transfer of technologies.

The researches of the influence of the offset agreements on the defense industry of the United States support this attitude. None of the government reports has found out the presence of a negative effect by the offsets on the defense industry of the United States. On the contrary - the jobs, lost in result of the concluded offset agreements, are less than the newly created jobs, connected with the implemented export sales.

The analysis of the literature brings the conclusion, that each country, which uses offset agreements, puts forward its own offset requirements by the purchase of defense products. This is predetermined by the fact, that worldwide the offset activity isn't regulated, coordinated or analyzed.

7) In result of implementing the offset the employment increases. In their analysis of the creation of new jobs in result of the implementation of offset transactions in South Korea, Jang, Ann and Kim share the opinion, that more than 130 countries use the offset transactions as an instrument for creation of jobs. [10]. The UAE, Peru, India, Saudi Arabia, Netherlands, Greece, Turkey and other countries rely on the offset programs to create jobs and export-oriented military industry. India has concluded contracts amounting to 3 billion USD for the acquisition of aircrafts Su-30 and helicopters Mi-17. Within these agreements, in India is established a joint venture for the production of helicopters. Saudi Arabia relies by means of offset agreements to reduce the high levels of unemployment (15-20\%), according to estimated data there will be 3640 new jobs. The Netherlands gives attractive conditions in the offset agreements to the foreign companies, which create and ensure new jobs by newly established companies and Research Institutions of its territory.

Analyzing the present state, the authors admit the importance of the offset for the creation of new jobs in South Korea and conclude that until 2017 in result of the offset transactions, 13125 new jobs are being expected. Resulting from the increased export of defense products, as a direct result of the concluded offset agreements, additional 17640 new jobs are foreseen.

A number of researchers support the opposite opinion. In their analysis Brauer and Dunne emphasize that there're no direct evidences of the creating of new and permanent jobs. Often the government authorities assert that the offset are going to create permanent jobs (2004). In the developed countries assure just from 
25 to $50 \%$ new, but not always permanent work. Despite of the decades of collaboration in the sphere of arms production with Germany, Argentina gets in fact no benefits. Brazil starts a wide local production of arms in the 30-s with different forms of offset, but only one of them (Helibras) can be defined as commercially realizable. The Indonesian experience for the creation of a military and civilian aircraft industry ended up with a debt of 570 million USD after the financial crisis in East Asia in 1997.

8) The offset transactions are characterized by high level of corruption risk. In his article Peter Platzgummer analyzes the cases of corruption by offset transactions (2013). He notices, that $40 \%$ of all cases of corruption by international transactions can be observed in the commerce with defense products. The main reason for these high levels are the huge amounts of the transactions, the independency of the deals and the individual trade agreements between the parties. The author categorizes the corruption practices in the offset transaction form the point of view of the complete process of concluding an agreement. There can be two kinds: before the signing of the contract and after the signing of the contract.

In their research Ben Magahy, Francisco Cunha and Mark Pyman are thoroughly studying the corruption in the defense sector (2010). According to them the main features of the offsets, causing corruption, can be reduced to:

- The offsets are being used as industrial political instruments by the governments, in order to affect the economic development of the country by means of purposeful interventions. The development of companies and industries through governmental support can generate economic interests. The offset transactions can turn into a convenient instrument for the governments to give assistance to local suppliers in return of given payoffs to officials and political parties. This way, in the worst case, the offset transactions can become means of payoff, and not means of achieving an industrial development.

- The offsets are being used as capital-intensive expenditures. The offsets are often being used directly or indirectly for facilitating the transfer of capitals into the economy of the importing country. In fact, the transfer of technologies is often used as key instrument for the implementing of offsets not only in the industrial development, but also in the developing countries. If the countries-importers are striving to take advantage of the offset transaction, they must aspire to make this in such sectors, where it's difficult to attract private investors. Those are such sectors of industry, which are capital-intensive. Hence, there exist several typical risks of corruption. Firstly, the high technologies and the capital-intensive defense industrial-technological bases are extended and technically are difficult to be understood without specialized knowledge. Second, for the reason, that the projects are implemented by means of awarding of specialized public tenders, the access to particular information regarding the transactions is strongly limited. Third, the number of agencies, participating in the process, increases considerably including political persons from the executive and legislative authorities, different officials, state employees, the company, which is main supplier, brokers, consultants and third parties, what makes it more difficult to follow duly the negotiations and to determine the potential irregularities, what on its hand makes corruption more probable.

- Non-transparency of the offset transactions. According to the researchers (2010), the corruption is prospering, when there is no transparency and there is lack of information regarding concluding of offset transactions. When the processes, decisions and activities are observed, it's less probable, that they will be involved in the corruption. The offsets are non-transparent trade instruments, what leads to probable and possible abuses.

- Distribution of definite tenders by few officials. These officials possess significant authorities concerning the division and the distribution of the offsets. As a result of this the officials may use this power to demand illegal enrichment. The exchange agreements, which are directed to long-term investments, offer attractive opportunities for such abuses.

In their analysis the authors (2010) classify the corruption into two kinds. In the first case, the corruption is limited to the extent of the offset transactions and bring the countries, which take part into the determination, negotiations, management and monitoring of the offset programs, to get undue compensations. Such examples can be: bribery of state employees, in order to receive cash without an actual action, purchasing of invoices from local companies by the contractor, not connected with the offsets and presenting them as compensations and others.

In the second case the corruption is carried out during the implementing of the offset transactions. Such examples can be projects, including large profit margins, which give the opportunity to redirect a part of the profit for illegal payments; compensating the state employees, who facilitate companies, directly or indirectly connected with the acquisition of defense products; compensating of state employees for offset projects, which are fictitious or there is no causal link between the result and the received money.

There are many specific opportunities for the corruption to infiltrate into offset programs (2010), (2016a). The 
most evident spheres, where the participants can take part into corruption activities, are connected with the process of elaboration of the offset programs. There are five main stages of the process of elaboration of the offset programs:

- Decision of the government to conclude offset transactions in order to guarantee the national security,

- The tendering procedures and submission of offers by the participating companies,

- Evaluation of the offers,

- Concluding a contract between the government and the main supplier, which can be performed simultaneously with the process of submission of the offers and indentifying the potential beneficiaries,

- Awarding of public contracts below the cost of the offset program.

The researchers (2010) emphasize that during each of these stage there exist opportunities for corruption of the various participating persons. They determine the corruption risk in the offset transactions as political, bureaucratic and as corruption in the private sector. In Table 1 are summarized the main corruption risks.

Table 1 Main corruption risks in case of offset transactions

Source: Ben Magahy, Francisco Vilhena da Cunha, Mark Pyman. Defence Offsets Addressing the risks of corruption \& raising transparency. Transparency International-UK, London, 2010

\begin{tabular}{|c|l|}
\hline Kind of corruption risk & \multicolumn{1}{c|}{ Corruption risks } \\
\hline \multirow{5}{*}{ Political corruption } & $\begin{array}{l}\text { - The established political interests, which desire to influence irregularly } \\
\text { the decision of the government about the necessity of purchasing defense } \\
\text { products by means of offset transactions; } \\
\text { - The established political interests, looking for guarantees for the } \\
\text { assigning of the contract to a precise supplier; } \\
\text { - Political figures, performing theft of the funds, granted for offset } \\
\text { transactions; } \\
\text { - Political figures, who accept payments from companies for assigning of } \\
\text { contracts. }\end{array}$ \\
\hline Bureaucratic corruption & $\begin{array}{l}\text { - Officials in the sphere of awarding of public contracts, who take } \\
\text { advantage of the offset transactions for paying of bribes; } \\
\text { - Officials in the sphere of awarding of public contracts, who accept illegal } \\
\text { payments for including particular conditions in the offset transaction; } \\
\text { - Officials in the sphere of awarding of public contracts, who accept illegal } \\
\text { payments for assigning of contracts according to the offset programs. }\end{array}$ \\
\hline $\begin{array}{c}\text { Corruption in the private } \\
\text { sector }\end{array}$ & $\begin{array}{l}\text { - Possible beneficiaries, offering payment or other benefits to the main } \\
\text { supplier in order to receive access to the contract according to offset } \\
\text { program; } \\
\text { - The companies-beneficiaries and the main supplier agree about illegal } \\
\text { payments to political persons or officials, in order to receive irregular } \\
\text { influence over the companies-suppliers; } \\
\text { - Intermediaries for offset transactions grant illegal payments to officials in } \\
\text { order to generate a demand for offset transactions. }\end{array}$ \\
\hline
\end{tabular}

\section{CONCLUSION}

The enhanced collaboration is the best way of progress. Precisely by means of a better coordination of the planning in the sphere of defense, which includes harmonization of the military requirements and the measures for increasing of the operating compatibility, unification and sharing of some abilities and structures for support, strengthening of the collaboration in the sphere of scientific researches and technological development, facilitating of the industrial cooperation and consolidation, optimizing of the tenders and elimination of the market impediments, the states-members will be able to develop their abilities using a more effective way, regarding the expenses, and without negative consequences for their sovereignty. 


\section{REFERENCES LIST}

Artyakov, V. and team, (2002). Military-technical collaboration of Russia with the foreign countries between the centuries. Moscow,

Ben Magahy, Francisco Vilhena da Cunha, Mark Pyman. (2010). Defence Offsets Addressing the risks of corruption \& raising transparency. Transparency International-UK, London,

lanakiev, G. (2006). The United States and the "Offsets in Defence Trade" Issue. // Proceedings of the 10th Annual International Conference on Economics and Security, Thessaloniki.

Jurgen Brauer, J. Paul Dunne, (2004). Arms Trade Offsets: What do We Know?, $8^{\text {th }}$ Annual Defence Economics and Security Conference University of the West of England, Bristol.

Nichev, N. (2017a). Offset Policies of the Countries of the European Union. New knowledge Journal of scence, Vol 6, No 1.

Nichev, N. (2017b). Perspectives for Use of the Offset Deals. New knowledge Journal of scence, Vol 6, No 1.

Peter Platzgummer, (2013). Arms trade offsets and cases of orruption: the usage of anti-corruption tools in special forms of arms acquisitions. International Public Management Review Vol. 14, Iss. 2.

Terziev V.K., Nichev N.B., (2016a). Bankov S.M. Corruption and national security. Международный научный журнал „Инновационная наука“ №10-3/2016, ООО „АЭТЕРНА“, Уфа.

Terziev, V., Nichev N., (2016b). Economic characteristics of offset transactions with defense products. Scientific journal „Economics and finance“ EDEX, Madrid, España. 